\title{
Transaction in non-cash payments through Ovo application: an Islamic judgment study by the Mazhab Syafi'i
}

\author{
Ahmad Arif Zulfikar \\ Magister of Law, Universitas Muhammadiyah Yogyakarta \\ Jl. Brawijaya, Geblagan, Tamantirto, Kec. Kasihan, Bantul, \\ Daerah Istimewa Yogyakarta 55183 \\ Email: ahmadarifzulfikar1@gmail.com \\ Pidayan Sasnifa \\ Faculty of Sharia UIN Sulthan Thaha Saifuddin Jambi \\ Jl. Arif Rahman Hakim No.111, Simpang IV Sipin, \\ Kec. Telanaipura, Kota Jambi, Jambi 36361 \\ Email: sasnifaberkah@gmail.com
}

\begin{abstract}
Abstrak
Seiring perkembangan teknologi, dewasa ini bayar-membayar bisa melalui ponsel pintar dengan aplikasi, yang semula transaksi untuk membayar barang maupun jasa hanya melalui website, kartu kredit maupun yang serupa. Dari sekian aplikasi ponsel pintar yang ada, salah satunya yakni OVO. Tujuan dari artikel ini adalah untuk menganalisis terkait layanan OVO dalam pembayaran transportasi online berdasarkan prespektif fikih syafi'iyah. Metode penelitian yang digunakan adalah hukum normatif, spesifikasi penelitian ini menggunakan deskriptif analisis yaitu berupa pemaparan secara rinci dan terukur yang dapat dianalisis dengan suatu norma hukum yang berlaku, sedangkan teknik analisis data menggunakan content analysis. Hasil penelitian menunjukkan bahwa berdasarkan pendapat dari perspektif Ulama' Syafi'iyah ditinjau dari segi tujuan serta transaksi aplikasi OVO akad yang digunakan adalah akad wadi'ah, namun aplikasi OVO menurut akad wadi'ah kategori pengguna secara ilmu fikih tidak sah sebab pengguna tak bisa mengambil uang atau saldo pada aplikasi, yang secara teori saldo maupun uang tersebut adalah hak milik pengguna sepenuhnya.
\end{abstract}

Kata Kunci: Hukum Islam, layanan OVO, transportasi online, figh syafi'iyah

\begin{abstract}
Along with the development of technology, nowadays payment can be done through smart phones with applications, those application enable transactions to pay for goods or services only through websites, credit cards or similar. OVO is one of smartphone applications available. The purpose of this article is to analyze OVO-related services in online transportation payments based on the perspective of shafi'i fiqh. The research method used is normative law, the specification of this study is descriptive analysis which is in the form of detailed and measurable exposure analyzed with an applicable legal norm, while data analysis techniques used is content analysis. The results show that based on the perspective of Ulema 'Syafi'iyah in terms of objectives and OVO application transactions, the contract used was a wadi'ah contract, but the OVO application according to the wadi'ah category of the user category in fiqh science was invalid because the user could not take money or balance on the application, while in theory the balance or money is should be the user's full ownership.
\end{abstract}

Keywords: Islamic law, OVO services, online transportation, shafi'i jurisprudence 


\section{Introduction}

J he increasing modernization of the times, human behaviour and norms are often inappropriate, especially when it comes to God. This then brings changes also in human interaction (muamalah) in terms of manifestations, which then emerge various methods and ways as a new face of the muamalah process or practice. As a phenomenon that occurs today, online-based transactions or through electronic media are carried out by the public because of the ease and function that is very helpful in terms of transactions used to purchase goods or services.

Ease in the transaction process is a positive impact of technology, especially in muamalah, in this case, the payment transaction process. One form of a shift in payment transactions is to pay via electronic money through an intermediary payment application on a smartphone. OVO is one of a variety of android applications that are able to make transactions via smartphone. This application can be downloaded at Google Play Store and Apple IOS. ${ }^{1}$

The price comparison offered by electronic payments is also another reason people use electronic money, the discount is around 10 to 20 thousand of the general rates. The price gap between cash and electronics then caused controversy among the scholars of muamalah shari'a. Statements from some of these experts namely that the discounted price is usury which leads to prohibition, because it is fäidah (additional benefits) from aqad qard loans, while the fiqh principle states:

Meaning: "Any receivables (loans) that bring benefits (profits), then that is usury." 2

While the rest consider it not included in the category of usury because it is an ijarah contract (lease) instead of qard, which is then known as al-ijärah almausüfah fi al-żimmah so that the discount can be categorized as an ataya (gift) whose legal origin is permissible.

Akad or al-aqd; engagements, agreements, and agreements. The bond of consent (the statement of binding) and qabul (the statement of acceptance of the bond) in accordance with the will of the influential Sharia. What is meant by "in accordance with the will of the Sharia" is that all ties which both (or more) parties do not do if they do not comply with the wishes of the sharia, "for example, agreeing to usury transactions, committing fraud or robbery of others. ${ }^{3}$

In addition to the qard and al-ijārah al-mausufah fi al-żimmah, there are also Shafi'i jurisprudence whose legal consequences may receive their orders from online transportation service providers. Studies on online transactions based on Islamic law have been widely carried out, one of which is by Pekerti and Herwiyanti stating that online trading transactions are permitted as long as they

${ }^{1}$ OVO, “About Us OVO,” 2020.

2 Muhammad Mușțafā Al-Zuhaili, AlQawāid Al-Fiqhiyah Wa Tațbiqātuha Fī AlMażāhib AlArba' (Dimasyq: Dār al-Fikr, 1949), p. 654.

${ }^{3}$ D R Muhammad, Model-Model Akad Pembiayaan Di Bank Syariah (Yogyakarta: UII Press, 2009), p. 18 
are based on prudential principles, ${ }^{4}$ and also research conducted by Hediana and Aly shows that online trading transactions through e-commerce is legal and can be done as long as by holding the principle of honesty. ${ }^{5}$ Whereas research conducted by Marjan Muhammad et al states that online trading transactions are lawful as long as they do not use credit card payments. ${ }^{6}$ Different cases with research conducted by Anam which shows that electronic money is a permitted and legal payment system. ${ }^{7}$

\section{Research method}

\section{Research design}

Normative legal research is the basis of this research method, so that there are systematic, principles and synchronization of laws, both vertically and horizontally so that the rules of the law do not result in conflicts between laws or comparative laws so that they seem harmonious. The specification of this study uses descriptive analysis in the form of detailed and measurable exposure that can be analysed with an applicable legal norm.

\section{Data and sources}

Data sources are the subjects that enable researchers to obtain, retrieve and collect complete, correct and accountable data. While the data source of this research is secondary data.

The data referred to as secondary is the data obtained from book texts whose function is to complete the primary data source. ${ }^{8}$ Secondary data sources are data obtained from the process of reviewing scientific textbooks, research results, and others. Secondary data acquisition comes from literacy texts, articles, and elaboration of articles and regulations.

\section{Analysis data}

Data analysis in this research is qualitative analysis. Secondary data obtained were analysed qualitatively to answer the problems in this research. In this study after the collection of legal materials, an analysis of legal materials is carried out in order to find conclusions, which are then referred to as Content Analysis. Normative research, as explained earlier, does not require field data and then analyses the things behind the data. Data or document analysis on the analysis of legal materials such as this can be expressed with the word "text". Content analysis shows that integrative and conceptual analysis methods tend to

\footnotetext{
${ }^{4}$ Retno Dyah Pekerti and Eliada Herwiyanti, “Transaksi Jual Beli Online Dalam Perspektif Syariah Madzhab Asy-Syafi'i," Jurnal Ekonomi, Bisnis, Dan Akuntansi 20, no. 2 (2018).

${ }^{5}$ Runto Hendiana and Ahmad Dasuki Aly, “Transaksi Jual Beli Online Perspektif Ekonomi Islam," Al-Mustashfa: Jurnal Penelitian Hukum Ekonomi Syariah 3, no. 2 (2016).

${ }^{6}$ Marjan Muhammad, Muhd Rosydi Muhammad, and Khalil Mohammed Khalil, "Towards Shari'ah Compliant e-Commerce Transactions: A Review of Amazon. Com," Middle-East Journal of Scientific Research 15, no. 9 (2013), p. 1229-1236.

${ }^{7}$ Choiril Anam, "E-Money (Uang Elektronik) Dalam Perspektif Hukum Syari'ah," Qawãnïn 2, no. 1 (2018).

${ }^{8}$ Marzuki, Metodologi Riset (Yogyakarta: PT Hanindita Offset, 1983), p. 56.
} 
be directed to find, identify, process, and analyse legal material to understand its meaning, significance, and relevance. ${ }^{9}$

\section{Results and discussion Definition of electronic money}

The origin of the word of electronic money came from English with the meaning of e-money. Electronic money is based on the understanding of the Bank for International Settlements (BIS), namely:

"Stored-value or prepaid products in which a record if the funds or value

available to a consumer is stored on an electronic device in the consumer's possession". ${ }^{10}$

This means the value stored or prepaid product in which an amount of money is stored in an electronic medium owned by someone.

In the most recent Bank Indonesia Regulation No.20 / 6 / PBI / 2018 in Chapter 1 General provisions, Article 1 number 3, there are rules relating to the understanding of electronic money, as below: Electronic Money is a means of payment that has the following elements: the elements below:

a. Issued on the basis of the value of money paid in advance to the issuer;

b. The value of money is stored electronically on a media server or chip; and

c. The value of electronic money managed by the issuer is not a deposit as referred to in the Act governing banking ${ }^{11}$

The conclusion obtained from the above terminology is that electronic money is electronic money with a value similar to cash stored on electronic media, servers or chip cards through top-ups (charging balances) to be used as a non-cash transaction tool, and the issuance of this electronic money conducted by a party that has a license from Bank Indonesia, unlike what is intended in the banking law, electronic money does not include deposits, so it does not interest and the Deposit Insurance Corporation (LPS) does not guarantee it.

\section{Variety of e-money}

The forms of electronic money on the market vary not just one, according to the functions and types they carry. In terms of the codification of the cardholder's identity, electronic money is divided into two, namely registered and unregistered. Registered, that is, the identity of the holder of the electronic money has been registered and recorded by the issuer, while the unregistered opposite, that is, the cardholder's identity is not recorded by the issuer. Then Bank Indonesia provides a maximum limit for each type of electronic money, namely five million rupiahs (IDR 5,000,000) on registered, and one million rupiah (IDR 1,000,000, -) on

\footnotetext{
${ }^{9}$ Bungin Burhan, Metodologi Penelitian Kualitatif (Jakarta: Raja Grafindo, 2001).

10 Bank for International Settlements, Implications for Central Banks of the Development of Electronic Money (Basle: Bank for International Settlements, 1996).

${ }^{11}$ Bank Indonesia, "Peraturan Bank Indonesia Nomor No20/06/PBI/2018" (2018), Pasal 1 Angka 3.
} 
unregistered..$^{12}$ Then the electronic money is also divided into two based on the media to store it, namely server-based and chip-based. ${ }^{13}$

Judging from the validity period, electronic money is also divided into two, namely reloadable and disposable, reloadable is a type of electronic money that supports refill while disposable does not support refilling if the value is used up. ${ }^{14}$

Then there are two kinds of electronic money in terms of coverage, namely single-purpose and multi-purpose. single-purpose is one type of e-money that is capable of carrying out only one type of economic transaction, and multi-purpose is capable of carrying out many types of economic transactions. ${ }^{15}$

In terms of scope of use, e-money has two forms, namely close loop and open loop, referred to as close-loop if e-money can be used only in places owned by the issuer, otherwise if the use of e-money is not limited as a means of paying In a publisher's place, the scope is wider, so it is called an open-loop. ${ }^{16}$

\section{OVO application in online transportation payments}

Non-cash payments are also launched by Grab which is a competitor of Gojek in the online transportation business, Grab then provides OVO as a noncash pay feature, which was previously called Grab Pay. The name change occurred after Grab cooperated with PT Visionet International, which is the issuer of emoney, and its operation has obtained a permit from Bank Indonesia. ${ }^{17}$

In general, the services and features offered by OVO are not much different from Go pay, which is used to pay for services owned by Grab such as Grab food, Grab bike, Grab Express, and others, but also can be used on third party service transactions, which of course have been determined by OVO or grab, other features such as transfer from one account to another can also be used even transfer to a bank account provided that the account has been upgraded to the primary. OVO balances do not have an expiration period, can be valid for life. ${ }^{18}$

\section{OVO services in online transportation payments based on Shafi'iyah fiqh perspectives. \\ Online transportation based on the opinion of Islamic Law}

Animal camels in the time of the Prophet were usually used and functioned as vehicles, even in war. The strength of power in these animals when traveling in the middle of the desert becomes a positive value from the camel. Even so, camels are not like horses that are able to accelerate quickly. Tools and transportation vehicles used at the time, both between villages and cities, namely donkeys, camels, horses, and horse-drawn carriages. The journey of the people of that era

\footnotetext{
${ }^{12}$ Bank Indonesia, Peraturan Bank Indonesia Nomor No20/06/PBI/2018.

${ }^{13}$ Ibid.

14 Bank Indonesia, "Surat Edaran Bank Indonesia Nomor 11/11/DASP Tentang Uang Elektronik" (2018).

${ }^{15} \mathrm{H}$ Veithal Rivai, Andria Permata Veithzal, and Ferry Novindra Idroes, Bank and Financial Institution Management (Yogyakarta: Raja Grafindo Persada, 2007), p. 1367.

${ }^{16}$ Bank Indonesia, Peraturan Bank Indonesia Nomor No20/06/PBI/2018.

${ }^{17}$ Grab Indonesia, “KETENTUAN LAYANAN: Transportasi, Pengiriman Dan Logistik,” 2020.

${ }^{18}$ Grab Indonesia, “OVO Dan Pembayaran,” 2020.
} 
was on foot, but for those who were able to certainly use the vehicles above. In this connection, the mounted animals and other means of public transport are vehicles that God created for humans so that they can drive. Available in Qs. Yasin: 41-42 which means:

"And a sign (the greatness of Allah) for them is that we transport their descendants in a ship full of cargo, and we create (also) for them (other transports) as they drive." 19

With the large number of people who continue to grow, the available facilities are not enough, then various vehicles and facilities are created by God related to human needs so as to facilitate humans in establishing relationships with each other. Hundreds of decades passed, in the early 20th century, humans who during that time used animals as mounts, at that time transportation of machines began to appear, motorcycles, cars, trains, and also planes. Basically this, God has told us for 14 centuries ago, where humans have not yet arrived at the knowledge of technology in both motorized vehicles and planes. And this culture, about the understanding of animals as mounts and primary transportation, did not recede at all until the early 20th century.

It is mentioned in the Word of God in Qs. An-Nahl: (8) which means:

"And (it has created) horses, mules, and donkeys, so that you will ride them

and (make them) adornments. And Allah created what you did not know :

(An-Nahl: 8) ".20

Allah glorifies and spoiled people in this world with various facilities. However, human gratitude to God is very little. Human nature always asks for its rights to be fulfilled even more, but forgets gratitude and carries out its obligations to God who has provided all the facilities and necessities of his life. In the word of God it is mentioned in Surah Al-Israak: (70) which means:

"And verily We glorified the children of Adam, we transported them on land and in the sea, we gave them sustenance from the good and we exaggerated them with perfect advantages over most of the creatures We have created. (Al Israak: 70). ${ }^{21}$

The provisions of Allah as contained in the An-Nahl verse 8, namely vehicles such as (in terms of use) with horses and camels will be created as a means of human transportation, began to be shown gradually in the early 20th century. As explained in HR. Ahmad, Al-Bukhari, Muslim, and others, that vehicles with super speed technology will emerge, both land and air vehicles, supersonic aircraft for example. And today sophisticated means of transportation continue to emerge in line with the development of modernization. Below is the sound of the hadith in which there is a description of more sophisticated transportation technology:

"Then I was approached by an animal called Buroq, which was taller than a donkey but shorter than Baghol, whose every step was as far as the eye

\footnotetext{
${ }^{19}$ Departemen Agama RI, Al-Qur'an Dan Terjemahannya (Bandung: Diponegoro, 2013), p. 444.

${ }^{20}$ Ibid.

${ }^{21}$ Ibid.
} 
could see. I was taken on it, then we left until we came to the sky of the world. " (Narrated by Ahmad, Al-Bukhari, Muslim, and others). ${ }^{22}$

Humans have mastered the development of technology to enable humans to build sophisticated vehicles. Previously travelled on foot for days, now only in a matter of hours using motorbikes and cars. Come to a city or country that used to be a matter of months, now it can be reached in a matter of hours using a plane. The creation of these vehicles is in line with the high mobility due to the increasing human population.

Now in Indonesia alone there are three types of transportation, namely land, sea, and air transportation. The most popular vehicles of the three types of the lane are often functioned by the whole community, especially Indonesia as a means of transportation compared to other lane vehicles namely land transportation. Vehicles or transportation can be distinguished based on their characteristics into two, public and private vehicles. Basically, a motorcycle is classified as private transportation, but lately, the function of this motorbike is not only as private transportation but also as public transportation, that is, the public can use services to travel or deliver goods from a certain point to the destination at a cost that has been set. Two-wheeled online transportation (motorbike) is public transportation similar to most motorcycle taxis, which has a function for public transportation but has a modern impression due to its integration with today's technology.

Online motorcycle taxis are motorcycle taxis which with their integration with technology through the use of applications on smartphones can make it easier for customers to find motorcycle taxis ranging from transportation, delivery of goods to the purchase of goods services moreover, can order various kinds of food, so the community at large especially in cities with dense activities are also jammed which is sure to be polemic, and the presence of this online motorcycle taxi is a convenience for people in their daily needs, of course by highlighting the features of technological advancements. In terms of Islamic law, online transportation is halal. Because there is no evidence about the prohibition, based on the rules of Fiqh which:

"Basically, all forms of muamalah can be done unless there is an argument that forbids it". ${ }^{23}$

From the above rules it is understood that in the affairs of the world including in muamalah, humans are given freedom related to the rules in accordance with their welfare. With this statement, all transaction methods originating from humans are allowed as long as they remain in the corridor of shara'.

${ }^{22}$ Kitab Ahmad Ahmad, "Hadist No. 2243," in Kitab Sembilan Imam (Lidwah Pustaka iSoftware, n.d.).

${ }^{23}$ Wardi Muslich Ahmad, Fiqh Muamalat (Jakarta: Amzah, 2010). 


\section{OVO services based on Syafiiyah fiqh perspectives}

OVO application is a product that has electronic services, especially in the case of financial transactions, which in this discussion OVO service products are objects of an agreement between OVO and the user. Based on the object of shafi'i manhaj must meet the five legal requirements of a contract, one of which is that the object of the contract must be clear and known by the parties to the transaction, this condition is also agreed upon by other madhab scholars, hanafiyah, malikiah, and hanabilah.

If it does not meet these requirements, it can certainly cause a cause and effect of the contract, related to these consequences or consequences, scholars disagree. Manhaj Shafi' $i$ considers that if the conditions are not fulfilled because the opinion of the Shafi'i ulama is full of clarity of the identity of the goods as a condition and is part of the in'iqod conditions, as explained by the Doctor of Sheikh Wahbah Zuhaili in his essay al-Figh al-Islämi wa Adillatuhu as follows:

Meaning:

"The object of the contract must be something valuable that is permissible to use based on the opinion of Sharak, the holy is not unclean, must already exist, can be handed over, and known by the transaction, all of these conditions are agreed upon by all the mazdhabhama scholars, only the unclear object of the contract is making the contract broken based on the opinion of Hanafiyah scholars, and making the contract null and void based on the opinion of the majority of Islamic scholars'. ${ }^{24}$

The same thing was mentioned by the Shafi'ite scholars in the book of al-Figh al-Manhajī 'alā Madzhabi al-Imām al-Shäfí $i$ explained that:

Meaning:

"It is not valid a contract where the parties to the transaction do not know clearly about the object of the transaction, which is unclear which can lead to disputes. In fact, in this case, containing ghoror, it is known that the Prophet forbade transactions containing ghoror. Then the transaction is invalid for objects that are not clearly known by the parties or one of the parties that transact ". ${ }^{25}$

Similar information is also explained by other Shafi'ite scholars in a book called Häshiyatu al-Bujayramī 'alä Sharhi al-Manhaji namely by Shaikh Sulaiman bin Muhammad bin Omar al-Bujayromī assyafi'I that, relating to the object of the contract that every party in the transaction must know it even must be known in detail by the person making the transaction. Based on his argument, this requirement provides an interpretation of the clarity, not only of the object of the contract but also the person making the transaction knows exactly the parties to the transaction, meaning that there is a need for further understanding of the object of the contract even though it is clear. ${ }^{26}$

${ }^{24}$ Wahba Zuhaili, “Al-Fiqhu Al-Islami Wa Adillatu Juz 5” (Damaskus: Al-Fikri, 2005), p. 3360.

25 Mustofa Al-Khon, Mustofa Al-Bhigho, and Ali As-Syarbaji, Al-Fikhu Al-Manhaji Ala Madzhabil Imam as-Syafi'i (Damaskus: Qarul Qolam, 1992), p. 64.

${ }^{26}$ Syekh Sulaiman Bin Muhammad Bin Umar Al Bujairomii Assyafi'I, “Hasyatul Bujairomi Ala Syarhil Manhaj, Juz 2" (Mesir: Al-halabi, 1950), p. 182. 
Information about goods and services is an obligation that must be fulfilled and given as a business or trade actor in muamalah, because goods and services are objects of the transaction. The measurement of the emergence of problems or disputes between parties conducting transactions is also related to the level of correctness and incorrectness of the information provided. Transactions that occur between OVO application users and OVO parties when viewed in terms of their own transactions can be likened to an ijarah contract, but based on the opinion of the ulama Syafi'iyah ijarah is a contract of the benefits of an object or service together with certain wages because the use of the benefits of goods as the object of the contract, as explained in the book of al-Fighu al-Manhaj 'ala Mazdhabi asSyāfi $i$, which explains that there are four (4) ijarah pillars namely, the person who transacts, the Kabul consent agreement, the clarity of goods, and there is a ujrah. ${ }^{27}$

Transaction processes in the OVO system can also be relied on in the qardh contract. Qardh etymologically is al-qath'u (القطع) which means piece. ${ }^{28}$ Deductions in the context of a qardh contract are deductions derived from the property of the person who gives money. Whereas according to the term interpreted as lending property to others without expecting anything in return. In terminology, the meaning of borrowing is giving up the property to the person who uses it to return it instead one day. ${ }^{29}$ According to the terms of fiqh experts (faqih), al-qardh is giving a treasure to others to be returned without any additional, which is permitted by the scholars.

In Al-Qur'an the letter Al-Hadid verse 11, Q.S. At-Taghabun verse 17 and Al-Baqarah verse 245, Allah SWT also gave information that the person who gave the loan 'al-qardh' actually gave a loan to Allah SWT, meaning to spend wealth in the way of Allah. In harmony with lending wealth to God, humans are also called to lend to each other, as part of community life. The sentence qardhan hasanan in verse 245 of Al-Baqarah means a good loan, that is infaq in the way of Allah. Another meaning is giving a living to the family and also prayer beads and taqdis (washing) ${ }^{30}$

The pillars of qardh are shighat qardh which is a qabul (receiving consent), The Parties Involved in qardh are lenders (lenders) and borrowers (debtors) and Lent Items. Then the requirements of the qard are aqad qardh. The capability in carrying out the contract and the assets lent is clear in size.

Goods lent in qard should be able to be handed over and can be used as ordered goods (muslam fih), that is, goods that have economic value (may be used according to shara') and their characteristics are known because they are eligible as orders. Regarding the types of goods of Syafi'iyyah and Malikiyyah scholars, they do not require the assets to be debated in the form of objects so that it is possible to derive benefits (services) that can be explained by nature. This is because for all

${ }^{27}$ Al-Khon, Al-Bhigho, and As-Syarbaji, Al-Fikhu Al-Manhaji Ala Madzhabil Imam as-Syafi'i.

${ }_{28}$ Al-Zuhaili, Al-Figh Al-Mu'amalat Al-Maliyah (2002, n.d.).

${ }_{29}$ Abdullah Al-Mushlih, Shalah Ash- Shawi, and Ma La Yasa' at-Tajira Jahluhu, Fikih Ekonomi Keuangan Islam, trans. Abu Umar Basyir (Jakarta: Darul Haq, 2008), p. 254.

${ }^{30}$ Ibnu Katsir, Tafsir Ibnu Katsir (Jakarta: Pustaka Imam Asy-Syafi'i, 2006), p. 498. 
those who may be traded in a way greeting may be deferred, while for those greetings may be on benefits (services), as well as objects in general.

In the view of Syafi'iyah scholars, it is permissible with any property that can be used as dependents, such as money, seeds, and qimiy assets such as animals, immovable objects and others, which of course there is clarity in size, whether in measurements, scales, numbers, or lengths. so, it's easy to return.

In addition, because OVO is an application that functions as a tool to save money that is converted in electronic form that can be used whenever and wherever needed, the transaction is oriented towards the wadi'ah contract. Syafi'iyah scholars regarding the wadiah contract argue as follows:

In the Kifäyatu al-akhyār book, it is stated that wadiah is a language "the name for the goods or assets which are entrusted by the owner or his representative to others to be safeguarded". 31

This is in line with the information described in the book of Fathu al-Qorib al-mujib: "wadi'ah is a language spoken for something that is entrusted to others to be guarded". 32

However, the purpose of the expression already shows the meaning of the wadi'ah contract, but it must be remembered that the meaning is still in the form of meaning in terms of language, whereas based on the opinion of the term namely: "pronounced on the contract that gives legal consequences (for the person entrusted) "Based on the opinion of Zuhaili, wadi'ah is a mandate in safeguarding property that belongs to people through several ways. ${ }^{33}$

Related to the terms of goods and pillars of goods as safekeeping as explained in the book of al-Fiqhu al-Manhaji 'alä Madzhab Imäm al-Shafi ' $i$ namely as follows: the meaning of goods as safekeeping is the object of the wadiah contract conducted. Custodian items are items that are glorified by the Sharia, meaning that they are their own property and can be stored, even in the form of assets that are considered worthless or unclean, for example, dogs that are used for hunting. In addition, goods must not be left for safekeeping if they are not glorified by the Sharia, they may not be entrusted, for example, pigs. ${ }^{34}$ The goods deposited must be safeguarded by the person who received the deposit, and if the owner asks to return and the entrusted person does not deign to return until the item is damaged, of course, he must bear the compensation..$^{35}$

The guarantee of the recipient of the item being deposited is not an obligation, unless he does not do the work as he should or does the jinayah for the item deposited.

\footnotetext{
${ }^{31}$ Misbah Mustafa, Abu Bakar Bin Muhammad Al-Husain Kifayatul Akhyar, Juz 2 (Surabaya: Al Haromain, 2005), p. 11.

${ }^{32}$ Muhammad bin Qosi Al-Ghozi, Fathul Qhorib Al-Mujib (Jakarta: Dar al Kutub al Ilmiyah, 2003), p. 41.

33 Imail Nawawi, Ikih Muamalah Klasik Dan Kontemporer: Hukum Perjanjian,Ekonomi, Bisnis,Dan Sosial (Jakarta: Ghalia Indonesia, 2012), p. 205.

${ }^{34}$ Al-Khon, Al-Bhigho, and As-Syarbaji, Al-Fikhu Al-Manhaji Ala Madzhabil Imam as-Syafi'i.

${ }^{35}$ Musthafa Dib Al-Bugha and D A Pakihsati, Fikih Islam Lengkap Penjelasan Hukum-Hukum Islam Madzhab Syafi'i (Media Zikir, 2009), p. 322.
} 
"The owner of the item may request the item to be returned at any time and the person entrusted can return the item at any time". ${ }^{36}$

Explained in the book al-Figh al-Manhajī 'alā Mazhabi ash-Shafi' $i$.

A wadiah contract is a contract that has a jawaz nature (permitted), that is, each party making a transaction can decide on cancellation at any time without the permission of the other party, and vice versa, the owner can request the goods at any time. If the item is requested by the owner of the property, the person who receives the item must return the item as best he can (according to the condition of the person who is entrusted), as in the word of Allah SWT take it to the owner, but he wants to release the contract for the goods deposited between him and the item'.

Based on the explanation and explanation above, it indicates that the contract or transaction related to OVO if based on Shafi'i figh is a transaction that has a clear contract and purpose for the function of the goods, the terms and conditions contained in the application and OVO's official website. If it is associated with borrowing or debt, OVO has similarities between the two, but if it is seen from the cancellation or the taking of assets, OVO is categorized in wadi'ah because the collection of assets can be done at any time considering that the deposited assets are the property that is entirely the user's property. Retrieval of this asset is also cancellation of the contract.

\section{Conclusion}

The electronic payment feature prepared by online transportation in Indonesia has received a Bank Indonesia license including OVO. The value held by this type of electronic money is the same as cash, which is issued after going through a top-up, which is stored electronically in a media on a server basis, and this electronic money is used for non-cash transaction media.

In terms of objectives and transactions, based on the opinion of the Ulema Syafi'iah the OVO application system uses a wadi'ah contract and as an OVO user related to the wadi'ah contract is fiqh permissible because its users as depositors can take money or balances that are the user's full ownership any time through the application.

\section{References}

Ahmad, Kitab Ahmad. "Hadist No. 2243." In Kitab Sembilan Imam. Lidwah Pustaka i-Software, n.d.

Ahmad, Wardi Muslich. Figh Muamalat. Jakarta: Amzah, 2010.

Al-Bugha, Musthafa Dib, and D A Pakihsati. Fikih Islam Lengkap Penjelasan HukumHukum Islam Madzhab Syafi'i. Media Zikir, 2009.

Al-Ghozi, Muhammad bin Qosi. Fathul Qhorib Al-Mujib. Jakarta: Dar al Kutub al Ilmiyah, 2003.

Al-Khon, Mustofa, Mustofa Al-Bhigho, and Ali As-Syarbaji. Al-Fikhu Al-Manhaji Ala Madzhabil Imam as-Syafi'i. Damaskus: Qarul Qolam, 1992.

\footnotetext{
36 Suamsuddin Muhammad Bin Abil Abbas Ahmad Bin Hamzah Syhabudin al-Romli, Nihayatul Muhtaj Ila Syarhil Minhaj Juz 6 (Beirud: Darul Fikri, 1984), p. 115.
} 
$230 \mid$ Ahmad Arif Zulfikar \& Pidayan Sasnifa

Al-Mushlih, Abdullah, Shalah Ash-Shawi, and Ma La Yasa' at-Tajira Jahluhu. Fikih Ekonomi Keuangan Islam. Translated by Abu Umar Basyir. Jakarta: Darul Haq, 2008.

Al-Zuhaili. Al-Fiqh Al-Mu'amalat Al-Maliyah. 2002, n.d.

Al-Zuhaili, Muhammad Mușțafā. AlQawāid Al-Fiqhiyah Wa Tațbiqātuha Fì AlMażāhib Al-Arba'. Dimasyq: Dār al-Fikr, 1949.

Anam, Choiril. “E-Money (Uang Elektronik) Dalam Perspektif Hukum Syari'ah.” Qawãnïn 2, no. 1 (2018).

Bank for International Settlements. Implications for Central Banks of the Development of Electronic Money. Basle: Bank for International Settlements, 1996.

Bank Indonesia. Peraturan Bank Indonesia Nomor No20/06/PBI/2018 (2018).

- - - Surat edaran Bank Indonesia Nomor 11/11/DASP tentang uang elektronik (2018).

Burhan, Bungin. Metodologi Penelitian Kualitatif. Jakarta: Raja Grafindo, 2001.

Departemen Agama RI. Al-Qur'an Dan Terjemahannya. Bandung: Diponegoro, 2013.

Grab Indonesia. "KETENTUAN LAYANAN: Transportasi, Pengiriman Dan Logistik," 2020.

- - - "OVO Dan Pembayaran," 2020.

Hendiana, Runto, and Ahmad Dasuki Aly. "Transaksi Jual Beli Online Perspektif Ekonomi Islam." Al-Mustashfa: Jurnal Penelitian Hukum Ekonomi Syariah 3, no. 2 (2016).

Katsir, Ibnu. Tafsir Ibnu Katsir. Jakarta: Pustaka Imam Asy-Syafi'i, 2006.

Marzuki. Metodologi Riset. Yogyakarta: PT Hanindita Offset, 1983.

Muhammad, D R. Model-Model Akad Pembiayaan Di Bank Syariah. Yogyakarta: UII Press, 2009.

Muhammad, Marjan, Muhd Rosydi Muhammad, and Khalil Mohammed Khalil. "Towards Shari'ah Compliant e-Commerce Transactions: A Review of Amazon. Com." Middle-East Journal of Scientific Research 15, no. 9 (2013).

Mustafa, Misbah. Abu Bakar Bin Muhammad Al-Husain Kifayatul Akhyar, Juz 2. Surabaya: Al Haromain, 2005.

Nawawi, Imail. Ikih Muamalah Klasik Dan Kontemporer: Hukum Perjanjian,Ekonomi, Bisnis,Dan Sosial. Jakarta: Ghalia Indonesia, 2012.

OVO. “About Us OVO," 2020.

Pekerti, Retno Dyah, and Eliada Herwiyanti. "Transaksi Jual Beli Online Dalam Perspektif Syariah Madzhab Asy-Syafi'i." Jurnal Ekonomi, Bisnis, Dan Akuntansi 20, no. 2 (2018).

Rivai, H Veithal, Andria Permata Veithzal, and Ferry Novindra Idroes. Bank and Financial Institution Management. Yogyakarta: Raja Grafindo Persada, 2007.

Suamsuddin Muhammad Bin Abil Abbas Ahmad Bin Hamzah Syhabudin alRomli. Nihayatul Muhtaj Ila Syarhil Minhaj Juz 6. Beirud: Darul Fikri, 1984.

Syekh Sulaiman Bin Muhammad Bin Umar Al Bujairomii Assyafi'I. "Hasyatul Bujairomi Ala Syarhil Manhaj, Juz 2." Mesir: Al-halabi, 1950.

Zuhaili, Wahba. "Al-Fiqhu Al-Islami Wa Adillatu Juz 5." Damaskus: Al-Fikri, 2005. 